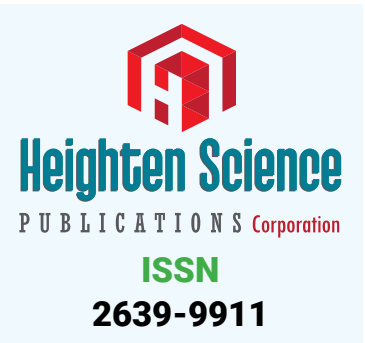

*Address for Correspondence: Dr. Melike Ertem, RN, PhD, Abant Izzet Baysal University, Psychiatric Nursing Department, Bolu, Turkey, Tel: +90-530-252-8027; Email: melike_yonder@hotmail.com

Submitted: 28 December 2016 Approved: 15 May 2017

Published: 16 May 2017

Copyright: @ 2017 Ertem M. This is an open access article distributed under the Creative Commons Attribution License, which permits unrestricted use, distribution, and reproduction in any medium, provided the original work is properly cited

D) Check for updates
Review Article

\section{Caring Difficulties of Parents' Towards Children with Cerebral Palsy}

\author{
Melike Ertem* \\ Abant Izzet Baysal University, Psychiatric Nursing Department, Bolu, Turkey
}

\section{SUMMARY}

Children with cerebral palsy may have one or more of mental, psychomotor, visual, audio or speech problems. Not being a well-defined disease with clear boundaries, it is regarded as a set of conditions caused by various reasons. In this regard, children with $\mathrm{CP}$ have to depend on their families or caregivers and cope with physical, mental, social and economic problems due to their condition. Therefore, it turns out to be crucial to determine the needs of the family with children with $\mathrm{CP}$ so that the programs that will assist them during this process can be developed. The study further revealed that the parents of the children with cerebral palsy needed information about controlling their children's behaviors and teaching them certain behaviors; they needed to talk to the teacher and/or therapist of the child; they needed support about making time for themselves; they needed community services about finding a care center or a nursery suitable for their children's needs.

\section{INTRODUCTION}

Cerebral palsy (CP) is the most common cause of neurological disorder of childhood $[1,2]$. According to data on CP prevalence among various countries, CP prevalence was reported as 2.1 per 1000 births in England and Scotland between 1984 and 1989 while it was 2.2 in Switzerland between 1990 and 1993 [3,4]. On the other hand, a multicenter and cross-sectional study in Turkey conducted in 1996 in 27 cities with 146 doctors and a total of 40939 children aged 0-16, CP prevalence among the over 2 years old children examined in terms of chronic diseases was similarly reported as 2 per 1000 [5].

Some problems are observed in children with cerebral palsy depending the location and size of the brain damage. These children may have one or more of mental, psychomotor, visual, audio or speech problems. Not being a well-defined disease with clear boundaries, it is regarded as a set of conditions caused by various reasons (Berker, Yalçın 2001). In this regard, children with CP have to depend on their families or caregivers and cope with physical, mental, social and economic problems due to their condition. Therefore, it turns out to be crucial to determine the needs of the family with children with CP so that the programs that will assist them during this process can be developed.Having a disabled child bring about some special matters for families. These problems can be categorised as: psychological issues, economical situation, education, life style, social environment, situation of disable of child [6].

Families with handicapped children often have needs such as understanding their children's diagnosis, planning their handicapped children's future, determining the effect of the condition on growth and development, meeting their social environment and intellectual needs, utilizing social resources and explaining their conditions to the rest of the family, the school and friends [7].

There are a lot of factors creating problems for those mothers undertaking the responsibility of giving care for their handicapped children such as economic difficulties, 
care difficulties, concerns about the transportation to rehabilitation centers, concern for the future, worry about their children falling behind and the question that who is going to look after their children after them [8]. A study conducted to determine the difficulties experienced by the families with a handicapped child reports that although these families are continuously worried about a possible accident or injury their children might face and concerned about the future, they receive no social support from their environment [9]. Therefore, it seems essential that the structure of these families, their needs, support within and from outside the family and situation of handicapped children be defined in detail $[10,11]$.

One of the most important help and support factors having a positive effect on the way the parents with handicapped children cope with difficulties is education. Education is a support system providing the knowledge and motivation required in dealing with difficulties [12]. Studies conducted with the families with handicapped children also report information need among the priority issues $[10,13]$. It was determined in another study that the depression level in the 20/26-month period following the educational session performed with the parents of children at various levels of mental disabilities went down while their coping skills increased [12]. It was also reported that the parents who had attended educational programs implemented to meet information needs and who expressed and shared their feelings possessed more information about and positive attitudes towards their handicapped children [14].

Parents with handicapped children need friends, emotional support and to realize that they are not alone. They may receive this support from other parents as well as other family members and friends [15]. However, it is reported that parents with handicapped children cannot get sufficient support in their social environment [9]. These parents need support from outside the family and expert assistance due to their inability to control the handicapped child's behaviors, inadequacies in social skills and emotional commitment and difficulties in having the child acquire several skills [16]. It is also reported that the concerns of the parents of the children with mental disabilities decrease when they meet a professional sympathizing with them while their feeling of self-confidence increase in the same situation $[12,17]$. State that a handicapped child needs to be provided with more care in comparison with his or her peers.

Some studies conducted with parents of handicapped children report parents' dissatisfaction with health care personnel; among the complaints are vague explanations about the child's handicap or condition, the being looked down on about their opinions, unclear education provided by the health care personnel and inadequacy of communication forms $[18,19]$. The fact that the disabled child depends on the caregiver due to the effect of $\mathrm{CP}$ on motor functions, the parents sometimes feel too much pressure caused by the continuous care-giving duties they undertake and the services for handicapped children are not sufficient are might have brought about this need. The parents need financial support in order to meet the cost of food, house rent, clothing, transportation, special equipment, therapy, special education and care of their handicapped children. Some studies point out that the financial needs of the families with handicapped children are at a worrying level $[8,13]$.

Cerebral palsy is a non-progressive motor disorder caused by a lesion during prenatal, natal or postnatal period in the pyramidal lines of the central nerve system (motor cortex, basal ganglion, cerebellum) [20]. Nevertheless, CP is a condition that affects not only the nerve system but also the whole lives of the child and the family. The parents with handicapped children have concerns for the future and continuously worried about a possible accident or injury their children might face [9].

\section{CONCLUSION AND SUGGESTION}

The study further revealed that the parents of the children with cerebral palsy needed information about controlling their children's behaviors and teaching them 
certain behaviors; they needed to talk to the teacher and/or therapist of the child; they needed support about making time for themselves; they needed community services about finding a care center or a nursery suitable for their children's needs. It could be suggested that a care and counseling center should be developed in order to coordinate the care, treatment and rehabilitation of the children with cerebral palsy, to provide support for the parents and family members and to ensure collaboration among those involved in the process.

\section{REFERENCES}

1. Jacobsson B, Hagberg G. Antenatal Risk Factors For Cerebral Palsy. Best Pract Res Clin Obstet Gynaecol. 2004; 18: 425-436. Ref.: https://goo.gl/K2qqEl

2. Çavuşoğlu, H. Çocuk Sağlığı ve Hastalıkları Hemşireliği, 9. Baskı. Ankara, Sistem Ofset Basımevi. $2011 ; 5-6$

3. Pharoah PO, Cooke T, Johnson MA, King R, Mutch L. Epidemiology Of Cerebral Palsy In England And Scotland, 1984-1989. Arch Dis Child Fetal Neonatal Ed. 1998; 79: 21-25. Ref.: https://goo.gl/S294BT

4. Nordmark E, Hägglund G, Lagergren J. Cerebral Palsy in Southern Sweeden I. Prevelance And Clinical Features. Acta Paediatrica. 2001; 90: 1271-1276. Ref.: https://goo.gl/n3VGXi

5. Yöneyman, F. Gürvit, G. Yusuf, M. Ro-Codec Çocuklarda Kronik Hastalıkların Sıklığı Tarama Çalışması. $1997 ; 83-84$.

6. Aktaş, E. Fiziksel Engelli Çocuk ve Ailesinin Evde Bakım Gereksinimine Işık Tutucu Araştırmaların Sistematik Incelemesi. Sağlık Bilimleri Enstitüsü, Çocuk Sağlığı ve Hastalıkları Hemşireliği Anabilim Dalı, Yüksek Lisans Tezi, İstanbul: Marmara Üniversitesi, 2010.

7. Meeropol E. Parental Needs Assessment: A Design For Clinical Nurse Specialist Practice. Pediatr Nurs. 1991; 17: 456-458. Ref.: https://goo.gl/sO3Nv7

8. Kazak AE, Marvin RS. Differences, Difficulties And Adaptation: Stress And Social Networks In Families with A Handicapped Child. Family Relations. 1984; 33: 67-77. Ref.: https://goo.gl/ULdWIR

9. Özsoy SA, Özkahraman Ş, Çallı F. Zihinsel Engelli Çocuk Sahibi Ailelerin Yaşadıkları Güçlüklerin Incelenmesi. Aile ve Toplum. 2006; 3: 69-76. Ref.: https://goo.gl/vBKZ1Y

10. Akçamete G, Kargın T. İşitme Engelli Çocuğa Sahip Annelerin Gereksinimlerinin Belirlenmesi. Özel Eğitim Dergisi. 1996; 2: 7-24. Ref.: https://goo.gl/exU2RM

11. Akmeşe P, Mutlu A, Günel MK. Serebral Paralizili Çocukların Annelerinin Kaygı Düzeyinin Araştırılması. Çocuk Sağlığı ve Hastalıkları Dergisi. 2007; 50: 236-240. Ref.: https://goo.gl/1MOeFQ

12. Kirkham MA. Two-Year Follow-Up Of Skills Training With Mothers Of Children With Disabilities. Am J Ment Retard. 1993; 97: 509-520. Ref.: https://goo.gl/0p004x

13. Bailey D, Simeonsson JR. Assessing Needs Of Families with Handicapped Infants. The Journal Of Special Education. 1988; 22: 117-127. Ref.: https://goo.gl/apyTZQ

14. Günayer H. Yetersizliğe Sahip Kardeşi Olanlarla, Olmayanların Yetersizliğe Yönelik Tutumlar ve Kaygı Düzeyleri Yönünden Karşılaştırılması. Özel Eğitim Dergisi. 1995; 2: 33-39. Ref.: https://goo.gl/vplbN0

15. Akkök F. Özürlü Çocuğu Olan Anne Babaların Kaygı ve Endişe Düzeyini Ölçme Aracının Geçerlilik ve Güvenirlik Çalışması. Psikoloji Dergisi. 1989; 7: 26-38. Ref.: https://goo.gl/8Z49sm

16. Karancı N, Farkı Özelliği Olan Çocuk Anne Babalarının Yaşadıkları. Karancı N. Editör. Farklııkla Yaşamak Aile ve Toplumun Farklı Gereksinimleri Olan Bireylerle Birlikteliği. I. Baskı, Ankara: Türk Psikologlar Derneği Yayınları. 1997; 9-54.

17. İçmeli C, Ataoğlu A, Canan Fm, Özçetin A. Zihinsel Özürlü Çocukları Olan Ebeveynler ile Sağlıkl Çocuklara Sahip Ebeveynlerin Çocuk Yetiştirme Tutumlarının Karşılaştııılması. Düzce Tıp Fakültesi Dergisi. 2008; 3: 21-28. Ref.: https://goo.gl/rWg51F

18. Hirose T, Ueda R. Long-Term Follow-Up Study Of Cerebral Palsy Children And Coping Behaviour Of Parents. J Adv Nurs. 1990; 15: 762-770. Ref.: https://goo.gl/khnFrA

19. Baysal ZB. Kronik Hastalıkların Çocuk ve Aile Üzerine Etkisi. Türk Psikiyatri Dergisi. 1993; 4: 273-280.

20. Algıer L, Conk Z, Çavuşoğlu H, ve ark. Serebral Felç. Conk Z. Editör. Çocuk Sağlığı ve Hastalıkları Hemşireliği Kitabı. I. Baskı, İstanbul:Vehbi Koç Vakfı Yayınları. 1997; 169-172. 